\title{
Pengaruh Pupuk Kalsium dan Kalium terhadap Pertumbuhan dan Kualitas Hasil Sawi Hijau (Brassica rapa L.)
}

\section{The Effects of Calcium and Potassium Fertilizer on Growth and Yield Quality of Mustard} (Brassica rapa L.)

\author{
Monica Intan Aryandhita dan Dody Kastono*) \\ Departemen Budidaya Pertanian, Fakultas Pertanian, Universitas Gadjah Mada \\ Jalan Flora No. 1, Bulaksumur, Sleman, Yogyakarta 55281, Indonesia. \\ *) Penulis untuk korespodensi E-mail: dodykastono@yahoo.co.id \\ Diajukan: 16 April 2020 /Diterima: 23 Maret 2021 /Dipublikasi: 25 Mei 2021
}

\begin{abstract}
Mustard (Brassica rapa L.) is one of vegetable that cultivated and consumed by people in Indonesia regions. Using calcium fertilizer in mustard cultivation is less important, so that it is applied when symptoms of calcium deficiency affect the quality of crop yield such as tip burn. Calcium fertilization could overcome calcium deficiency, but plant will undergo potassium deficiency as side effect. Foliar application of calsium fertilizer was used to avoid negative interaction between calcium and phosphate in the soil so that good quality yield and growth could be produced. The aim of this research is to determine interaction between foliar applied Ca fertilizer and $\mathrm{KCl}$ on mustard growth and quality, also the optimum concentration and dosage of foliar applied $\mathrm{Ca}$ fertilizer and $\mathrm{KCl}$. $\mathrm{A}$ research was conducted on AugustOctober 2019 at Kebun Percobaan Tri Dharma, Agriculture Faculty, Gadjah Mada University, Banguntapan, Bantul, Yogyakarta. The research used RCBD with two factors which were the concentration of calcium fertilizer $(0,2,4$, and $6 \mathrm{~g} / \mathrm{l})$ and the second factor was the dosage of $\mathrm{KCl}$ fertilizer (0, 100, 200, and $300 \mathrm{~kg} / \mathrm{ha})$. Concentration showed amount of calcium fertilizer mixed in a liter of water and dosage showed amount of fertilizer applied per plant. Result of the research showed that interaction between calcium concentration and phosphate dosage did not increase mustard growth and yield but had a potential in increasing texture and taste of mustard by applying 4 and $6 \mathrm{~g} / \mathrm{l}$ calcium concentration with $100 \mathrm{~kg} / \mathrm{ha}$ phosphate dosage, while 2 and $4 \mathrm{~g} / \mathrm{l}$ calcium concentration with $200 \mathrm{~kg} / \mathrm{ha}$ dosage could produce the most preferred mustard. Calcium fertilizer concentration increased mustard consumption index. The more amount of phosphate fertilizer dosage applied (>300 kg/ha) could decrease mustard fresh weight.
\end{abstract}

Keywords: calcium; potassium; fertilizer; mustard

\section{INTISARI}

Sawi hijau (Brassica rapa L.) merupakan salah satu jenis tanaman sayur yang dibudidayakan dan dikonsumsi oleh masyarakat di berbagai wilayah Indonesia. Pemupukan dengan menggunakan pupuk kalsium pada budidaya tanaman sawi hijau dipandang kurang penting sehingga pemupukan baru dilakukan ketika terjadi gejala kekurangan kalsium yang mempengaruhi kualitas hasil tanaman seperti terbakarnya ujung daun. Pemupukan kalsium dapat mengatasi defisiensi kalsium, namun memiliki efek samping berupa terjadinya defisiensi kalium pada tanaman. Perlakuan berupa aplikasi pupuk $\mathrm{Ca}$ secara foliar kemudian dilakukan untuk menghindari interaksi negatif antara unsur hara $\mathrm{Ca}$ dan $\mathrm{K}$ di dalam tanah sehingga dihasilkan tanaman dengan pertumbuhan dan kualitas yang baik. Penelitian ini 
dilaksanakan pada bulan Agustus-Oktober 2019 di Kebun Percobaan Tri Dharma Fakultas Pertanian, Universitas Gadjah Mada, Banguntapan, Bantul, Yogyakarta. Penelitian disusun dalam rancangan acak kelompok lengkap (RAKL) dengan dua faktor. Faktor pertama yaitu konsentrasi pupuk $\mathrm{Ca}$ (kalsium) yang diaplikasikan secara foliar dan terdiri dari 0, 2, 4, dan 6 $\mathrm{g} / \mathrm{l}$ serta faktor kedua yaitu dosis pupuk $\mathrm{KCl}$ yang langsung dibenamkan pada lubang tanam dan terdiri dari $0,100,200$, dan $300 \mathrm{~kg} / \mathrm{ha}$. Konsentrasi menunjukkan banyaknya pupuk yang dicampurkan ke dalam per liter air, sedangkan dosis menunjukkan banyak pupuk yang diaplikasikan atau diterima per tanaman. Hasil penelitian menunjukkan bahwa interaksi antara konsentrasi kalsium dan dosis kalium tidak memperbaiki pertumbuhan dan hasil sawi, namun konsentrasi kalsium $2 \mathrm{~g} / \mathrm{l}$ secara nyata meningkatkan indeks konsumsi sawi hijau. Terdapat potensi perbaikan kualitas, terutama tekstur dan rasa dari aplikasi konsentrasi kalsium 4 dan $6 \mathrm{~g} / \mathrm{l}$ dengan dosis kalium mulai $100 \mathrm{~kg} / \mathrm{ha}$, sedangkan konsentrasi kalsium 2 dan $4 \mathrm{~g} / \mathrm{l}$ dengan dosis kalium $200 \mathrm{~kg} / \mathrm{ha}$ menghasilkan sawi hijau yang paling disukai oleh koresponden. Dosis pupuk $\mathrm{KCl}$ tidak mempengaruhi pertumbuhan dan hasil sawi hijau, dan semakin tinggi dosis mulai $300 \mathrm{~kg} / \mathrm{ha}$ justru menurunkan berat segar tajuk sawi hijau.

Kata kunci: kalium; kalsium; pupuk; sawi hijau

\section{PENDAHULUAN}

Sawi hijau (Brassica rapa L.) merupakan salah satu jenis tanaman sayur yang umum dikonsumsi dan dibudidayakan oleh masyarakat di berbagai wilayah di Indonesia. Sawi hijau dikonsumsi untuk memenuhi kebutuhan gizi tubuh manusia karena tanaman ini memiliki berbagai kandungan nutrisi, yaitu protein, lemak, karbohidrat, kalsium, fosfor, zat besi, vitamin A, $B$, dan $C$, serta serat yang baik untuk sistem pencernaan manusia. Dalam setiap $100 \mathrm{~g}$ sawi hijau terkandung nutrisi berupa $95 \mathrm{~g}$ air; 1,2 g protein; 0,2 g lemak; 1,2 g karbohidrat; $5.800 \mathrm{IU}$ vitamin $A ; 0,04 \mathrm{mg}$ vitamin $B 1 ; 0,07 \mathrm{mg}$ vitamin B2; 0,5 mg niasin; $53 \mathrm{mg}$ vitamin C; $102 \mathrm{mg}$ kalsium; 2 mg zat besi; 27 mg magnesium; 37 $\mathrm{mg}$ fosfor; $180 \mathrm{mg}$ kalium; dan $100 \mathrm{mg}$ natrium (Opena and Tay, 1994; DGDK, 2012). Dengan tren hidup sehat di kalangan masyarakat yang semakin tinggi dan pertambahan jumlah penduduk setiap tahunnya, dapat diperkirakan bahwa permintaan pasar terhadap komoditas sayur akan terus meningkat setiap tahunnya.

Kalsium merupakan salah satu unsur hara makro sekunder yang penting bagi tanaman dan perannya dalam tanaman telah banyak diteliti secara luas dalam kaitannya sebagai nutrisi tanaman. Kalsium diperlukan dalam proses pertumbuhan dan perkembangan tanaman, khususnya akar dan tunas tanaman. Kalsium berperan dalam mengatur permeabilitas sel tanaman, menjaga keutuhan struktur dan fungsi membran tanaman, mengatur transportasi ion dan mengontrol pertukaran ion dalam tanaman (Yucel et al., 2013; Faranso dan Susila, 2015). Pada tanah inseptisol atau regosol, kandungan kalsium tertukar dalam tanah termasuk sedang, namun kekurangan unsur hara kalsium pada tanaman dapat terjadi akibat translokasi kalsium yang tidak merata. Hal ini disebabkan kalsium tidak dapat ditranslokasikan dari jaringan tua ke jaringan muda (Blakemore et al., 1987; Rosmarkam dan Yuwono, 2002). Gejala kekurangan kalsium akan mempengaruhi nilai ekonomi dan kualitas hasil tanaman seperti terhambatnya pertumbuhan pucuk (titik tumbuh), tanaman kerdil, serta ujung daun terbakar (tip burn) yang sering terjadi pada 
tanaman sayur daun (Easterwood, 2016; Khan et al., 2017).

Pemupukan secara foliar merupakan salah satu cara pemupukan yang tepat digunakan karena dapat secara cepat mengatasi translokasi kalsium yang tidak merata dalam tanaman. Dengan menggunakan aplikasi pupuk secara foliar, pembatasan penyerapan kalsium akibat kandungan humus tanah yang tinggi, $\mathrm{pH}$ tanah rendah, serta terbentuknya kompleks khelat $\mathrm{Ca}^{2+}$ dan asam organik dapat dihindari sehingga hara kalsium dapat terserap secara optimal oleh tanaman (Ochmian, 2012). Penambahan hara kalsium melalui pemupukan memiliki efek samping berupa defisiensi unsur hara $\mathrm{K}$ akibat terjadinya penghambatan penyerapan unsur $\mathrm{K}$ saat kandungan $\mathrm{Ca}$ tinggi. Defisiensi $\mathrm{K}$ dalam tanaman dapat menyebabkan proses fotosintesis dan aktivitas enzim tanaman terganggu (Rosmarkam dan Yuwono, 2002). Penelitian ini kemudian dilakukan untuk mengetahui interaksi dan pengaruh aplikasi pupuk kalsium secara foliar dan pupuk kalium yang dibenam pada lubang tanam sawi hijau serta konsentrasi optimal pupuk $\mathrm{Ca}$ dan dosis optimal pupuk $\mathrm{KCl}$ sehingga dihasilkan tanaman yang bertumbuh baik dan berkualitas.

\section{BAHAN DAN METODE}

Penelitian ini telah dilaksanakan pada bulan Agustus-Oktober 2019 di Kebun Percobaan Tri Dharma, Fakultas Pertanian, Universitas Gadjah Mada, Banguntapan, Bantul, Yogyakarta dan Laboratorium Manajemen Produksi Tanaman sub-Laboratorium IImu Tanaman, Fakultas Pertanian, Universitas Gadjah Mada, Yogyakarta. Alat-alat yang digunakan dalam penelitian ini meliputi polibag berukuran $20 \mathrm{~cm} \times 20 \mathrm{~cm}$, alat bercocok tanam, alat tulis, gelas ukur $1.000 \mathrm{ml}$, alat semprot, selotip, timbangan analitik dengan kapasitas maksimal $500 \mathrm{~g}$ dengan tingkat ketelitian 0,05 gram, mikroskop binokuler digital olympus (Germany), optilab mikroskop digital tipe advanced, oven (ELE Internasional A-01-285) dengan suhu maksimal $250^{\circ} \mathrm{C}$, meteran, jangka sorong, luxmeter, termohigrometer, labu ukur $100 \mathrm{ml}$, pipet ukur, test tube, saringan, mortar dan pestel, gelas obyek, gelas beker $50 \mathrm{ml}$, kertas saring Whatman No. 40, pipet ukur 5 dan $10 \mathrm{ml}$, kertas koran, spectronic 21D Milton Roy, dan kamera digital. Bahan penelitian meliputi benih sawi hijau varietas Tosakan, pupuk $\mathrm{KCl}$ Mahkota, pupuk Kalsigro 98, tanah inseptisol atau regosol, aseton, selulosa asetat (cat kuku), aquades, insektisida Imidor $50 \mathrm{SL}$, pupuk kandang, pestisida nabati berasal dari sari bawang putih, dan air.

Penelitian dilaksanakan menggunakan Rancangan Acak Kelompok Lengkap (RAKL) dua faktorial dengan ulangan sebanyak tiga kali sebagai blok. Faktor perlakuan pertama yang diberikan berupa pemberian pupuk $\mathrm{Ca}$ foliar dengan konsentrasi $0 \mathrm{~g} / \mathrm{l}$ (C0), $2 \mathrm{~g} / \mathrm{l}$ (dosis 0,13 $\mathrm{g} /$ tanaman) (C1), $4 \mathrm{~g} / \mathrm{l}$ (dosis 0,27 g/tanaman) (C2), dan $6 \mathrm{~g} / \mathrm{l}$ (dosis 0,4 g/tanaman) (C3) serta faktor perlakuan kedua berupa pemberian pupuk $\mathrm{KCl}$ dengan dosis $0 \mathrm{~kg} / \mathrm{ha}(\mathrm{K} 0), 100 \mathrm{~kg} / \mathrm{ha}$ (setara 0,4 g/polibag) (K1), $200 \mathrm{~kg} / \mathrm{ha}$ (setara 0,8 g/polibag) (K2), dan $300 \mathrm{~kg} / \mathrm{ha}$ (setara 1,2 g/polibag) (K3). Pengaplikasian pupuk KCl dilakukan satu kali saat tanaman berusia $22 \mathrm{hspt}$ (hari setelah pindah tanam), sedangkan pupuk Ca disemprotkan satu hari setelah tanam dan setiap satu minggu sekali saat tanaman berusia 
7, 14, dan 21 hst dengan volume $200 \mathrm{ml}$ per tanaman. Dalam satu unit percobaan berisi 10 tanaman dengan tiga ulangan sehingga total tanaman yang dibutuhkan sebanyak 480 tanaman.

Pengambilan sampel tanaman destruktif dilakukan sebanyak dua kali saat tanaman berusia 7 dan 14 hst, sedangkan panen dilakukan saat tanaman berusia 25-30 hst. Sampel destruktif diambil sebanyak dua tanaman dan tanaman panen diambil sebanyak tiga tanaman.

\section{HASIL DAN PEMBAHASAN}

Berdasarkan penelitian yang telah dilakukan, maka dapat diperoleh hasil morfofisiologi dan hasil sawi hijau varietas Tosakan yang ditanam dengan kombinasi perlakuan konsentrasi $\mathrm{Ca}$ dan dosis $\mathrm{KCl}$. Perubahan hasil variabel-variabel fisiologi pada tanaman menyebabkan perubahan morfologi tanaman setelah $28 \mathrm{hst}$.

Tabel 1. Kandungan klorofil a, b, total, kerapatan stomata dan lebar bukaan stomata tanaman sawi hijau pada 28 hst

\begin{tabular}{|c|c|c|c|c|c|c|c|c|c|c|}
\hline Perlakuan & \multicolumn{2}{|c|}{ Klorofil a } & \multicolumn{2}{|c|}{ Klorofil b } & \multicolumn{2}{|c|}{ Klorofil Total } & \multicolumn{2}{|c|}{ Jumlah Stomata } & \multicolumn{2}{|c|}{ LB Stomata } \\
\hline \multicolumn{11}{|l|}{ Konsentrasi Ca: } \\
\hline $0 \mathrm{~g} / \mathrm{l}$ & 0,47 & a & 0,18 & $\mathrm{a}$ & 0,65 & $\mathrm{a}$ & 175,69 & c & 5,69 & a \\
\hline $2 \mathrm{~g} / \mathrm{l}$ & 0,43 & $\mathrm{a}$ & 0,16 & $\mathrm{a}$ & 0,59 & $\mathrm{a}$ & 232,36 & a & 5,11 & a \\
\hline $4 \mathrm{~g} / \mathrm{l}$ & 0,44 & a & 0,16 & $\mathrm{a}$ & 0,6 & $a$ & 185,17 & $\mathrm{bc}$ & 5,17 & a \\
\hline $6 \mathrm{~g} / \mathrm{l}$ & 0,42 & $a$ & 0,15 & $a$ & 0,57 & $a$ & 211,72 & $a b$ & 5,52 & $a$ \\
\hline \multicolumn{11}{|l|}{ Dosis Pupuk KCl: } \\
\hline $0 \mathrm{~kg} / \mathrm{ha}$ & 0,44 & $p$ & 0,17 & $p$ & 0,61 & $p$ & 194,86 & $\mathrm{pq}$ & 5,52 & $p$ \\
\hline $100 \mathrm{~kg} / \mathrm{ha}$ & 0,45 & $p$ & 0,17 & $p$ & 0,62 & $\mathrm{p}$ & 220,89 & $\mathrm{pq}$ & 5,47 & $\mathrm{p}$ \\
\hline $200 \mathrm{~kg} / \mathrm{ha}$ & 0,44 & $p$ & 0,17 & $\mathrm{p}$ & 0,61 & $\mathrm{p}$ & 205,92 & $\mathrm{pq}$ & 5,24 & $\mathrm{p}$ \\
\hline $300 \mathrm{~kg} / \mathrm{ha}$ & 0,43 & $p$ & 0,15 & $\mathrm{p}$ & 0,58 & $\mathrm{p}$ & 183,28 & $q$ & 5,27 & $\mathrm{p}$ \\
\hline Interaksi Ca* $\mathrm{K}$ & \multicolumn{2}{|c|}{$(-)$} & \multicolumn{2}{|c|}{$(-)$} & \multicolumn{2}{|c|}{$(-)$} & \multicolumn{2}{|c|}{$(-)$} & \multicolumn{2}{|c|}{$(-)$} \\
\hline CV (\%) & \multicolumn{2}{|c|}{22,05} & \multicolumn{2}{|c|}{29.41} & \multicolumn{2}{|c|}{23,89} & \multicolumn{2}{|c|}{29,90} & \\
\hline
\end{tabular}

Keterangan:(-) menunjukan tidak ada interaksi; angka rerata yang diikuti huruf yang sama pada kolom yang sama menunjukan tidak adanya beda nyata pada uji DMRT $\alpha=5 \%$

Pada Tabel 1 terlihat bahwa perlakuan konsentrasi pupuk $\mathrm{Ca}$ memberikan pengaruh nyata terhadap kerapatan stomata yang dihitung dari jumlah stomata per satuan luas daun tertentu. Jumlah stomata daun tanaman sawi hijau dengan perlakuan konsentrasi Ca 2 g/l (C1) memiliki jumlah tertinggi dibandingkan perlakuan lainnya. Kerapatan stomata merupakan suatu karakteristik fisiologi yang penting dalam mengatur uap air yang hilang dari tanaman dan sebagai indikator ketahanan terhadap suhu tinggi dan umumnya dipengaruhi oleh suhu lingkungan dan juga genetik. Pengaplikasian pupuk $\mathrm{Ca}$ sejak tanaman muda dapat mempengaruhi pertumbuhan awal karena kecukupan hara dapat menghasilkan pertumbuhan tanaman yang baik sehingga genetik tanaman yang baik dapat terekspresikan dengan baik pula . 
Tabel 2. Tinggi tanaman dan jumlah daun sawi hijau berumur 7, 14,dan 28 hst

\begin{tabular}{|c|c|c|c|c|c|c|c|c|c|c|c|c|}
\hline Perlakuan & \multicolumn{2}{|c|}{ TT $7(\mathrm{~cm})$} & \multicolumn{2}{|c|}{ TT $14(\mathrm{~cm})$} & \multicolumn{2}{|c|}{ TT $28(\mathrm{~cm})$} & \multicolumn{2}{|c|}{ JD 7} & \multicolumn{2}{|c|}{ JD 14} & \multicolumn{2}{|c|}{ JD 28} \\
\hline \multicolumn{13}{|l|}{ Konsentrasi Ca: } \\
\hline $0 \mathrm{~g} / \mathrm{l}$ & 0,86 & $b$ & 1,10 & a & 1,54 & $a$ & 3,33 & a & 5,33 & a & 9,61 & a \\
\hline $2 \mathrm{~g} / \mathrm{l}$ & 0,68 & $\mathrm{~b}$ & 0,99 & a & 1,36 & $a$ & 2,83 & a & 5,08 & a & 9,11 & $a b$ \\
\hline $4 \mathrm{~g} / \mathrm{l}$ & 1,25 & $a$ & 1,08 & a & 1,58 & $\mathrm{a}$ & 3,50 & a & 5,04 & a & 8,33 & $b$ \\
\hline $6 \mathrm{~g} / \mathrm{l}$ & 0,91 & $\mathrm{~b}$ & 1,04 & $\mathrm{a}$ & 1,38 & $\mathrm{a}$ & 3,17 & $a$ & 5,00 & $\mathrm{a}$ & 8,67 & $a b$ \\
\hline \multicolumn{13}{|l|}{ Dosis KCl: } \\
\hline $0 \mathrm{~kg} / \mathrm{ha}$ & 0,76 & $q$ & 1,08 & $p$ & 1,60 & $\mathrm{p}$ & 3,67 & $\mathrm{p}$ & 5,21 & $p$ & 8,78 & $p$ \\
\hline $100 \mathrm{~kg} / \mathrm{ha}$ & 1,23 & $\mathrm{pq}$ & 1,01 & $\mathrm{p}$ & 1,47 & $\mathrm{pq}$ & 2,83 & $q$ & 5,29 & $\mathrm{p}$ & 9,17 & $\mathrm{p}$ \\
\hline $200 \mathrm{~kg} / \mathrm{ha}$ & 0,91 & $\mathrm{pq}$ & 1,00 & $p$ & 1,45 & $p q$ & 3,17 & $\mathrm{pq}$ & 4,83 & $p$ & 8,75 & $p$ \\
\hline $300 \mathrm{~kg} / \mathrm{ha}$ & 0,80 & $q$ & 1,14 & $p$ & 1,35 & q & 3,17 & $\mathrm{pq}$ & 5,13 & $p$ & 9,03 & $p$ \\
\hline Interaksi $\mathrm{Ca}^{*} \mathrm{~K}$ & \multicolumn{2}{|c|}{$(-)$} & \multicolumn{2}{|c|}{$(-)$} & \multicolumn{2}{|c|}{$(-)$} & \multicolumn{2}{|c|}{$(-)$} & \multicolumn{2}{|c|}{$(-)$} & \multicolumn{2}{|c|}{$(-)$} \\
\hline CV (\%) & \multicolumn{2}{|c|}{24,31} & \multicolumn{2}{|c|}{18,95} & \multicolumn{2}{|c|}{29,52} & \multicolumn{2}{|c|}{26,41} & \multicolumn{2}{|c|}{21,48} & \multicolumn{2}{|c|}{25,61} \\
\hline
\end{tabular}

Keterangan: (-) menunjukan tidak ada interaksi; angka rerata yang diikuti huruf yang sama pada kolom yang sama menunjukan tidak adanya beda nyata pada uji DMRT $\alpha=5 \%$

Tabel 3. Luas daun dan diameter batang sawi hijau pada 7, 14, dan 28 hst

\begin{tabular}{|c|c|c|c|c|c|c|c|c|}
\hline Perlakuan & \multicolumn{2}{|c|}{$\operatorname{LD} 7\left(\mathrm{~cm}^{2}\right)$} & \multicolumn{2}{|c|}{ LD $14\left(\mathrm{~cm}^{2}\right)$} & \multicolumn{2}{|c|}{ LD $28\left(\mathrm{~cm}^{2}\right)$} & \multicolumn{2}{|c|}{ DB $28(\mathrm{~cm})$} \\
\hline \multicolumn{9}{|l|}{ Konsentrasi Ca: } \\
\hline $0 \mathrm{~g} / \mathrm{l}$ & 7,08 & a & 54,35 & $a$ & 456,66 & $\mathrm{a}$ & 0,65 & $a$ \\
\hline $2 \mathrm{~g} / \mathrm{l}$ & 3,50 & $b$ & 50,63 & $\mathrm{a}$ & 411,65 & $a b$ & 0,64 & $\mathrm{a}$ \\
\hline $4 \mathrm{~g} / \mathrm{l}$ & 8,92 & a & 45,92 & $\mathrm{a}$ & 388,63 & $b$ & 0,70 & $\mathrm{a}$ \\
\hline $6 \mathrm{~g} / \mathrm{l}$ & 6,42 & $a b$ & 43,84 & $\mathrm{a}$ & 441,09 & $a b$ & 0,72 & $\mathrm{a}$ \\
\hline \multicolumn{9}{|l|}{ Dosis Pupuk KCl: } \\
\hline $0 \mathrm{~kg} / \mathrm{ha}$ & 7,92 & $p$ & 53,90 & $p$ & 453,21 & $p$ & 0,72 & $p$ \\
\hline $100 \mathrm{~kg} / \mathrm{ha}$ & 4,83 & $\mathrm{p}$ & 51,00 & $p$ & 432,40 & $\mathrm{pq}$ & 0,67 & $p$ \\
\hline $200 \mathrm{~kg} / \mathrm{ha}$ & 5,75 & $p$ & 44,93 & $p$ & 406,10 & $\mathrm{pq}$ & 0,68 & $p$ \\
\hline $300 \mathrm{~kg} / \mathrm{ha}$ & 7,42 & $p$ & 44,92 & $p$ & 406,31 & q & 0,63 & $p$ \\
\hline Interaksi Ca*K & \multicolumn{2}{|c|}{$(-)$} & \multicolumn{2}{|c|}{$(-)$} & \multicolumn{2}{|l|}{$(-)$} & \multicolumn{2}{|c|}{$(-)$} \\
\hline CV (\%) & \multicolumn{2}{|c|}{33,80} & \multicolumn{2}{|c|}{28,08} & \multicolumn{2}{|c|}{27,52} & \multicolumn{2}{|c|}{27,46} \\
\hline
\end{tabular}

Keterangan: (-) menunjukan tidak ada interaksi; angka rerata yang diikuti huruf yang sama pada kolom yang sama menunjukan tidak adanya beda nyata pada uji DMRT $\alpha=5 \%$

Tinggi tanaman dan daun merupakan ukuran tanaman yang sering diamati, baik sebagai indikator pertumbuhan maupun sebagai parameter yang digunakan untuk mengukur pengaruh lingkungan atau perlakuan awal yang diterapkan dalam suatu penelitian. Selain hal tersebut, pengamatan daun dapat didasarkan pada fungsinya sebagai penerima cahaya dan alat fotosintesis. Atas dasar hal tersebut, maka luas daun akan menjadi pilihan parameter utama karena laju fotosintesis per satuan tanaman pada kebanyakan kasus sebagian besar ditentukan oleh luas daun (Sitompul dan Guritno, 1995). Perlakuan konsentrasi pupuk Ca yang diaplikasikan secara foliar memberikan pengaruh nyata terhadap tinggi tanaman (Tabel 1) serta luas daun (Tabel 2) tanaman sawi hijau berumur $7 \mathrm{hst}$, sedangkan dosis pupuk $\mathrm{KCl}$ tidak berpengaruh nyata pada tinggi tanaman, jumlah daun, dan luas daun.

Hal ini menunjukkan bahwa perlakuan aplikasi pupuk kalsium secara foliar mampu 
meningkatkan penyerapan $\mathrm{Ca}$ pada tanaman sawi hijau muda. Kalsium memiliki peranan yang erat dalam pertumbuhan apikal, pembelahan sel, pengaturan permeabilitas sel, serta perkecambahan biji. Unsur hara Ca tidak dapat ditranslokasikan dari jaringan tua ke jaringan muda sehingga gejala defisiensi $\mathrm{Ca}$ akan mulai tampak dari organ tanaman muda. Dengan menggunakan aplikasi pupuk secara foliar, pembatasan penyerapan kalsium akibat kandungan humus tanah yang tinggi, $\mathrm{pH}$ tanah rendah, serta terbentuknya kompleks khelat $\mathrm{Ca}^{2+}$ dan asam organik dapat dihindari sehingga hara kalsium dapat terserap secara optimal oleh tanaman (Ochmian, 2012).

Tabel 3. Bobot segar dan kering tajuk dan akar tanaman sawi pada umur $7 \mathrm{hst}$

\begin{tabular}{|c|c|c|c|c|}
\hline Perlakuan & BST 7 (g) & BSA 7 (g) & BKT 7 (g) & BKA $7(g)$ \\
\hline \multicolumn{5}{|l|}{ Konsentrasi Ca: } \\
\hline $0 \mathrm{~g} / \mathrm{l}$ & $0,27 \quad a b$ & $0,03 \quad a b$ & $0,04 \quad a$ & $0,01 \quad a$ \\
\hline $2 \mathrm{~g} / \mathrm{l}$ & $0,19 \quad b$ & $0,23 \quad b$ & $0,08 \quad a$ & $0,01 \quad a$ \\
\hline $4 \mathrm{~g} / \mathrm{l}$ & $0,38 \quad a$ & $0,04 \quad a b$ & $0,05 \quad a$ & $0,01 \quad a$ \\
\hline $6 \mathrm{~g} / \mathrm{l}$ & $0,27 \quad a b$ & $0,04 \quad a$ & $0,04 \quad a$ & $0,01 \quad a$ \\
\hline \multicolumn{5}{|l|}{ Dosis Pupuk KCl: } \\
\hline $0 \mathrm{~kg} / \mathrm{ha}$ & $0,34 p$ & $0,35 p$ & $0,10 \quad p$ & $0,01 p$ \\
\hline $100 \mathrm{~kg} / \mathrm{ha}$ & $0,20 \quad q$ & $0,03 \quad p$ & $0,03 p$ & $0,01 \quad p$ \\
\hline $200 \mathrm{~kg} / \mathrm{ha}$ & $0,26 \mathrm{pq}$ & $0,33 p$ & $0,03 p$ & $0,01 \quad p$ \\
\hline $300 \mathrm{~kg} / \mathrm{ha}$ & $0,31 \mathrm{pq}$ & $0,04 p$ & $0,04 p$ & $0,01 \quad p$ \\
\hline Interaksi Ca*K & $(-)$ & $(-)$ & $(-)$ & $(-)$ \\
\hline CV (\%) & 26,37 & 29,94 & 56,05 & 22,30 \\
\hline
\end{tabular}

Keterangan: (-) menunjukan tidak ada interaksi; angka rerata yang diikuti huruf yang sama pada kolom yang sama menunjukan tidak adanya beda nyata pada uji DMRT $\alpha=5 \%$

Perlakuan konsentrasi pupuk Ca hanya memberikan pengaruh nyata terhadap bobot segar tajuk tanaman berumur 7 hst, sedangkan perlakuan dosis pupuk $\mathrm{KCl}$ tidak memberikan pengaruh nyata terhadap bobot segar dan kering tajuk dan akar tanaman sawi hijau berumur 7 hst (Tabel 3). Tanaman sawi hijau dengan perlakuan konsentrasi pupuk $\mathrm{Ca} 4 \mathrm{~g} / \mathrm{l}$ (C2) menghasilkan bobot segar tanaman paling tinggi dibandingkan perlakuan lainnya. Hal ini berbanding lurus dengan hasil variabel sebelumnya yaitu tinggi tanaman dan luas daun tanaman berumur 7 hst dengan perlakuan konsentrasi pupuk $\mathrm{Ca} \quad 4 \quad \mathrm{~g} / \mathrm{l}$ menghasilkan hasil terbaik dibandingkan perlakuan lainnya. Batang dan daun merupakan bagian dari tajuk tanaman sehingga ukuran maupun tingkat pertumbuhan bagian tanaman tersebut akan mempengaruhi hasil pertumbuhan tajuk tanaman. Tanaman dengan luas daun yang semakin lebar akan meningkatkan penyerapan sinar matahari oleh daun sehingga laju fotosintesis tanaman akan meningkat. Laju fotosintesis yang optimal dapat menghasilkan lebih banyak fotosintat sehingga pertumbuhan tanaman akan optimal dan dapat menghasilkan produktivitas yang optimal. 
Tabel 4. Bobot segar dan bobot kering tajuk serta bobot kering akar sawi 28 hst

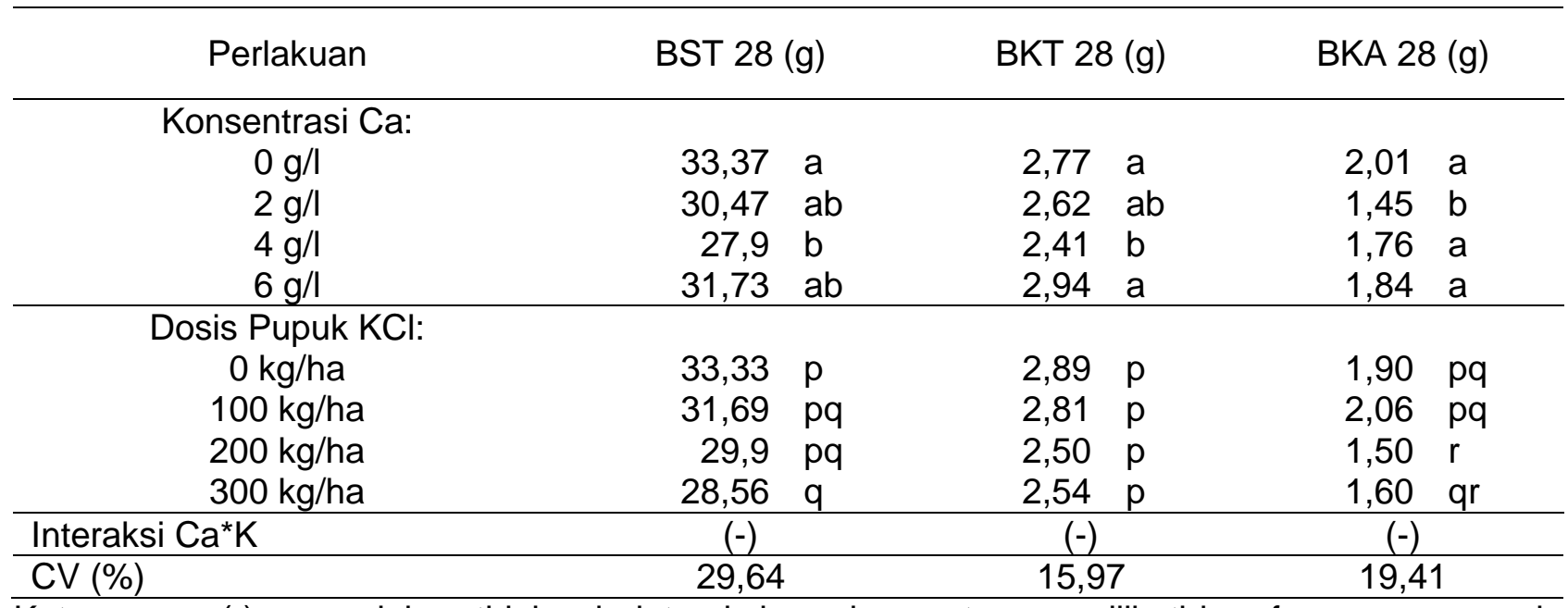

Keterangan: (-) menunjukan tidak ada interaksi; angka rerata yang diikuti huruf yang sama pada kolom yang sama menunjukan tidak adanya beda nyata pada uji DMRT $\alpha=5 \%$

Pada Tabel 4 dapat terlihat pengaruh nyata perlakuan konsentrasi pupuk $\mathrm{Ca}$ pada variabel bobot kering tajuk dan akar, sedangkan dosis pupuk $\mathrm{K}$ hanya mempengaruhi bobot kering akar tanaman sawi hijau berumur 28 hst secara nyata dan tidak terdapat interaksi nyata antara kedua perlakuan tersebut. Perlakuan konsentrasi pupuk $\mathrm{Ca}$ kontrol dan $6 \mathrm{~g} / \mathrm{l}$ menghasilkan bobot kering tajuk tertinggi, sedangkan seiring bertambahnya konsentrasi pupuk $\mathrm{Ca}$ yang diberikan justru semakin menurunkan bobot kering akar. Perlakuan dosis pupuk K 100 kg/ha menghasilkan bobot kering akar tertinggi. Hal ini menunjukkan bahwa perlakuan penyemprotan pupuk kalsium dengan konsentrasi 6 g/l secara foliar mampu menghindari interaksi negatif antara $\mathrm{Ca}$ dan $\mathrm{K}$ sehingga dihasilkan pertumbuhan tajuk terbaik, sedangkan peningkatan konsentrasi pupuk $\mathrm{Ca}$ dan dosis pupuk $\mathrm{K}$ menurunkan pertumbuhan akar karena terjadi penghambatan serapan antar unsur di dalam tanah yang menyebabkan berat akar justru menurun dengan penambahan pupuk yang dilakukan.

Tabel 5. Bobot segar akar tanaman pada umur 28 hst

\begin{tabular}{|c|c|c|c|c|c|}
\hline \multirow{2}{*}{$\begin{array}{c}\text { Dosis } \\
\mathrm{KCl}(\mathrm{kg} / \mathrm{ha})\end{array}$} & \multicolumn{4}{|c|}{ Konsentrasi Ca (g/l) } & \multirow{2}{*}{ Rerata } \\
\hline & 0 & 2 & 4 & 6 & \\
\hline 0 & $19,39 a$ & $11,82 \mathrm{bcd}$ & $12,47 \mathrm{abcd}$ & $13,22 \mathrm{abcd}$ & $14,22 p$ \\
\hline 100 & $13,43 \mathrm{abcd}$ & $13,53 a b c$ & $15,66 a b$ & $11,31 \mathrm{bcd}$ & $13,49 p$ \\
\hline 200 & $13,81 \mathrm{abc}$ & $8,77 \mathrm{~cd}$ & $10,48 \mathrm{bcd}$ & $11,53 \mathrm{bcd}$ & $11,15 q$ \\
\hline 400 & $11,82 \mathrm{bcd}$ & $7,66 \mathrm{~d}$ & $11,73 \mathrm{abcd}$ & $13,87 \mathrm{abc}$ & $11,27 \mathrm{q}$ \\
\hline Rerata & $14,62 \mathrm{a}$ & $10,44 a$ & $12,58 \mathrm{a}$ & $12,48 \mathrm{a}$ & $(+)$ \\
\hline
\end{tabular}

Keterangan: (+) menunjukan adanya interaksi; angka rerata yang diikuti huruf yang sama pada kolom yang sama menunjukan tidak adanya beda nyata pada uji DMRT $\alpha=5 \%$

Konsentrasi pupuk Ca dan dosis pupuk $\mathrm{K}$ memberikan pengaruh nyata terhadap bobot segar akar tanaman sawi hijau berumur 28 hst serta terdapat interaksi antara kedua perlakuan tersebut. Tabel 5 menunjukkan bahwa semakin tinggi konsentrasi dan dosis perlakuan pupuk, 
maka bobot segar akar yang dihasilkan semakin rendah. Umur tanaman dikotil berpengaruh terhadap kadar kalsium di dalam tanaman. Semakin tua umur tanaman, maka semakin tinggi kadar $\mathrm{Ca}$ di dalam organ tanaman. Tingginya kadar $\mathrm{Ca}$ dalam tanaman akan menghambat penyerapan $\mathrm{K}$ oleh tanaman akibat sifat antagonis kedua unsur tersebut. Ketidakseimbangan antara unsur $\mathrm{Ca}$ dan $\mathrm{K}$ menyebabkan gejala kekahatan pada salah satu unsur yang pada hal ini terjadi pada K (Sitompul dan Guritno, 1995).

Hal ini menyebabkan perlakuan pupuk $\mathrm{Ca}$ dan $\mathrm{K}$ menghasilkan hasil tanaman yang lebih rendah dibandingkan kontrol ketika seharusnya penambahan unsur hara berupa pupuk terhadap tanaman dapat meningkatkan hasil tanaman. Secara garis besar dapat dikatakan bahwa pemberian pupuk $\mathrm{Ca}$ foliar tanpa pemberian $\mathrm{K}$ ke tanah, menyebabkan penurunan bobot segar akar, sedangkan pemberian $\mathrm{Ca}$ foliar disertai pemberian $\mathrm{K}$ ke tanah pada umumnya tidak berpengaruh terhadap bobot segar akar. Bobot segar tertinggi diperoleh tanpa tambahan pupuk $\mathrm{Ca}$ maupun K. Pemberian $\mathrm{K}$ tanpa disertai pemberian $\mathrm{Ca}$ atau $\mathrm{Ca}$ konsentrasi rendah $(2 \mathrm{~g} / \mathrm{l})$, menurunkan bobot segar akar. Bila pemberian $\mathrm{K}$ dilakukan disertai pemberian $\mathrm{Ca}$ dengan konsentrasi lebih tinggi (4 atau $6 \mathrm{~g} / \mathrm{l}$ ) tidak mempengaruhi bobot segar.

Tabel 6. Indeks konsumsi sawi hijau

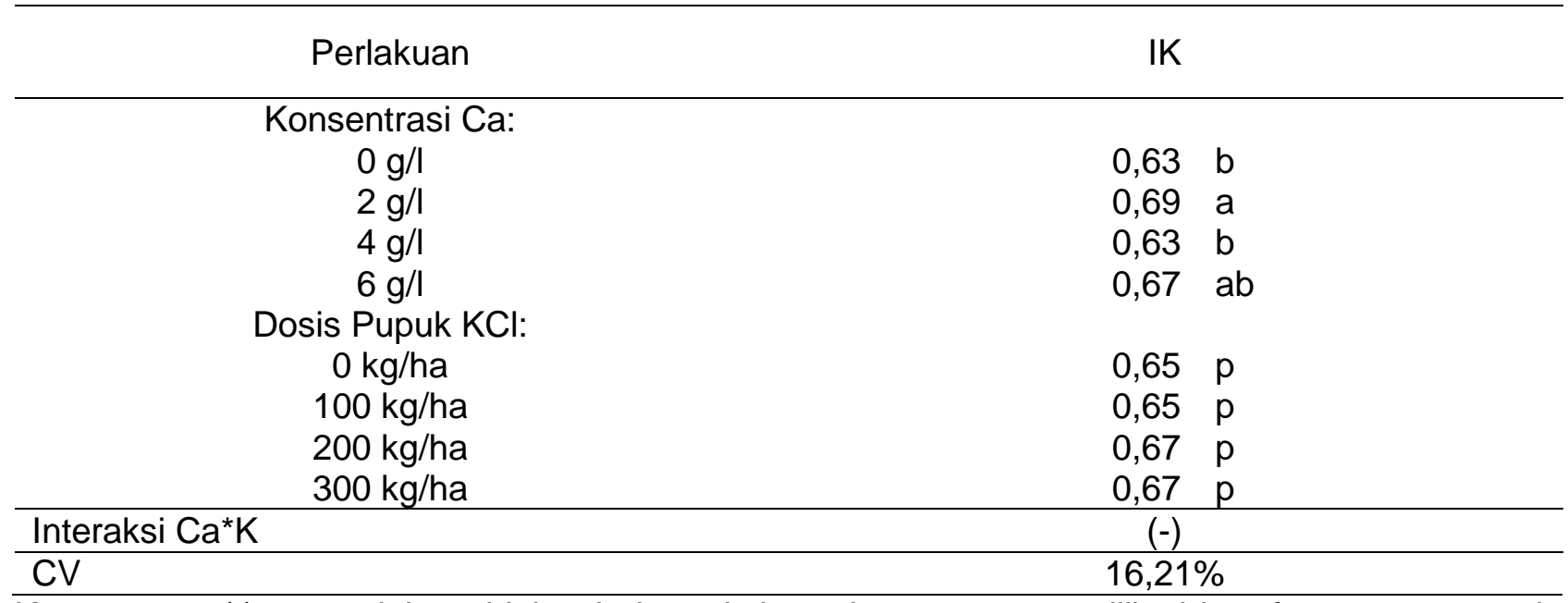

Keterangan: (-) menunjukan tidak ada interaksi; angka rerata yang diikuti huruf yang sama pada kolom yang sama menunjukan tidak adanya beda nyata pada uji DMRT $\alpha=5 \%$

Pada Tabel 6 dapat terlihat bahwa perlakuan konsentrasi pupuk $\mathrm{Ca}$ memberikan pengaruh nyata terhadap indeks konsumsi tanaman sawi hijau berumur 28 hst. Perlakuan konsentrasi pupuk Ca 2 g/l menghasilkan indeks konsumsi tertinggi. Tanaman sawi hijau dengan perlakuan ini berarti memiliki pertumbuhan tajuk yang lebih tinggi dibandingkan pertumbuhan akarnya sehingga lebih banyak bagian tanaman yang dapat dikonsumsi. Jika dipandang dari segi ekonomis, maka hal ini menguntungkan bagi tanaman sawi yang dibudidayakan untuk komersil karena semakin banyak bagian yang 
dapat dijual sehingga keuntungan yang didapatkan lebih tinggi.

Pengujian organoleptik atau sensori merupakan cara pengujian menggunakan indera manusia sebagai alat utama untuk menilai mutu produk. Penilaian menggunakan alat indera ini meliputi spesifikasi mutu kenampakan, bau, rasa, dan konsistensi/tekstur serta beberapa faktor lain yang diperlukan untuk menilai produk tersebut. Pengujian organoleptik yang dilakukan oleh panelis ahli membutuhkan minimal 6 orang. Jika pengujian dilakukan oleh panelis terlatih yang bukan merupakan ahli, maka jumlah minimal panelis adalah 9 orang, sedangkan untuk panelis non standar (konsumen) dibutuhkan minimal sebanyak 30 orang (Kementerian Kelautan dan Perikanan, 2006).

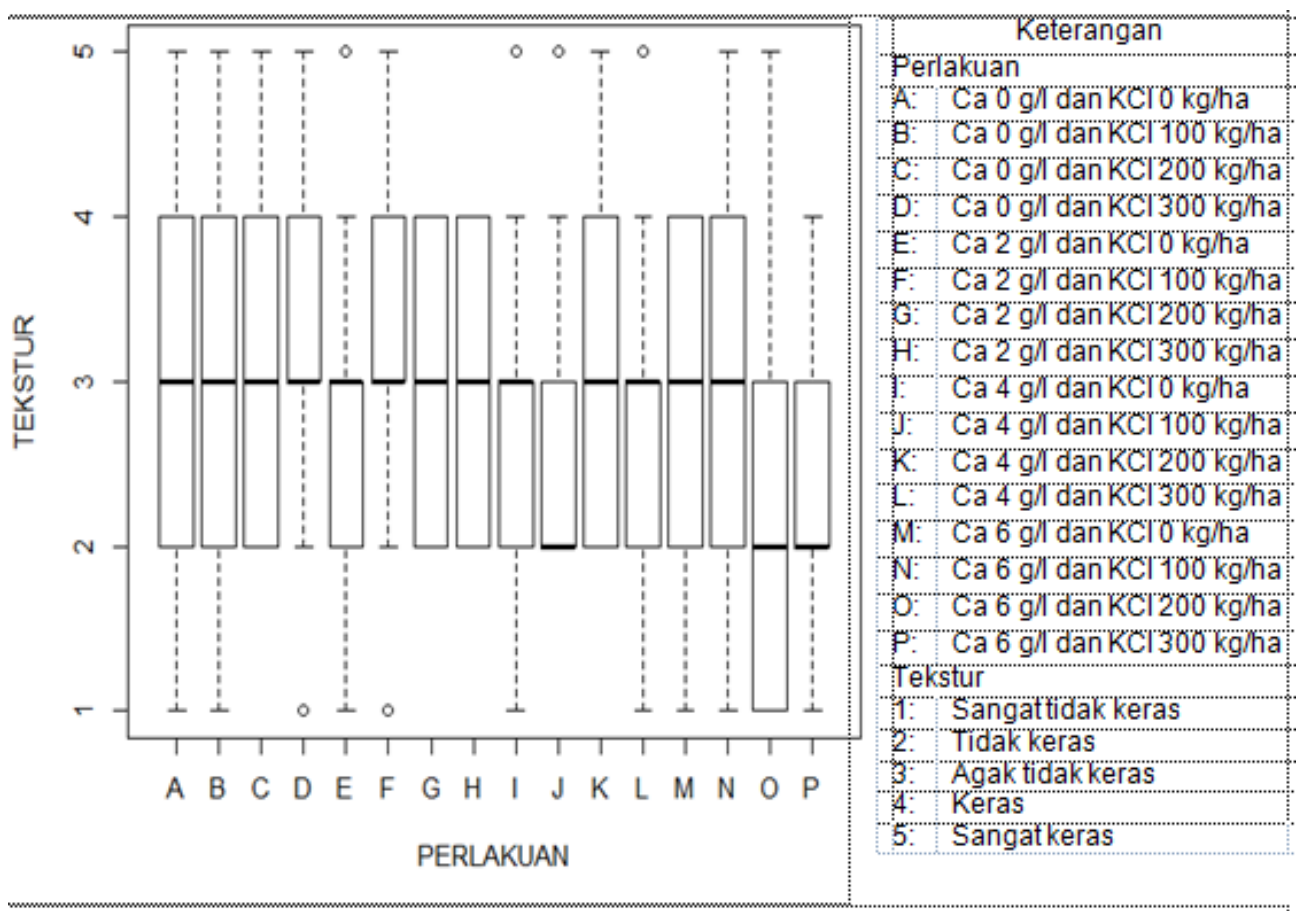

Gambar 1. Boxplot uji organoleptik tekstur hasil sawi hijau

Dari pengujian yang dilakukan (Gambar 1), didapatkan bahwa rata-rata nilai tengah tekstur sawi hijau berada pada angka 3 yang berarti sawi hijau agak tidak keras, sedangkan tekstur yang berada pada angka 2 (tidak keras) dihasilkan oleh daun tanaman sawi hijau dengan perlakuan konsentrasi $\mathrm{Ca} 4 \mathrm{~g} / \mathrm{l}$ dan dosis $\mathrm{KCl}$ $100 \mathrm{~kg} / \mathrm{ha}$, konsentrasi $\mathrm{Ca} 6 \mathrm{~g} / \mathrm{l}$ dan dosis $\mathrm{KCl}$ $100 \mathrm{~kg} / \mathrm{ha}$, serta konsentrasi Ca $6 \mathrm{~g} / \mathrm{l}$ dan dosis
$\mathrm{KCl} 300 \mathrm{~kg} / \mathrm{ha}$. Kalsium berperan dalam membentuk kalium-pektat pada dinding sel tanaman yang menyebabkan dinding sel menjadi lebih kuat, namun penambahan $\mathrm{Ca}$ melebihi batas optimal dapat menghambat penyerapan unsur lain yang juga berperan dalam dinding sel sehingga justru menyebabkan tekstur hasil tanaman menjadi lebih lunak 


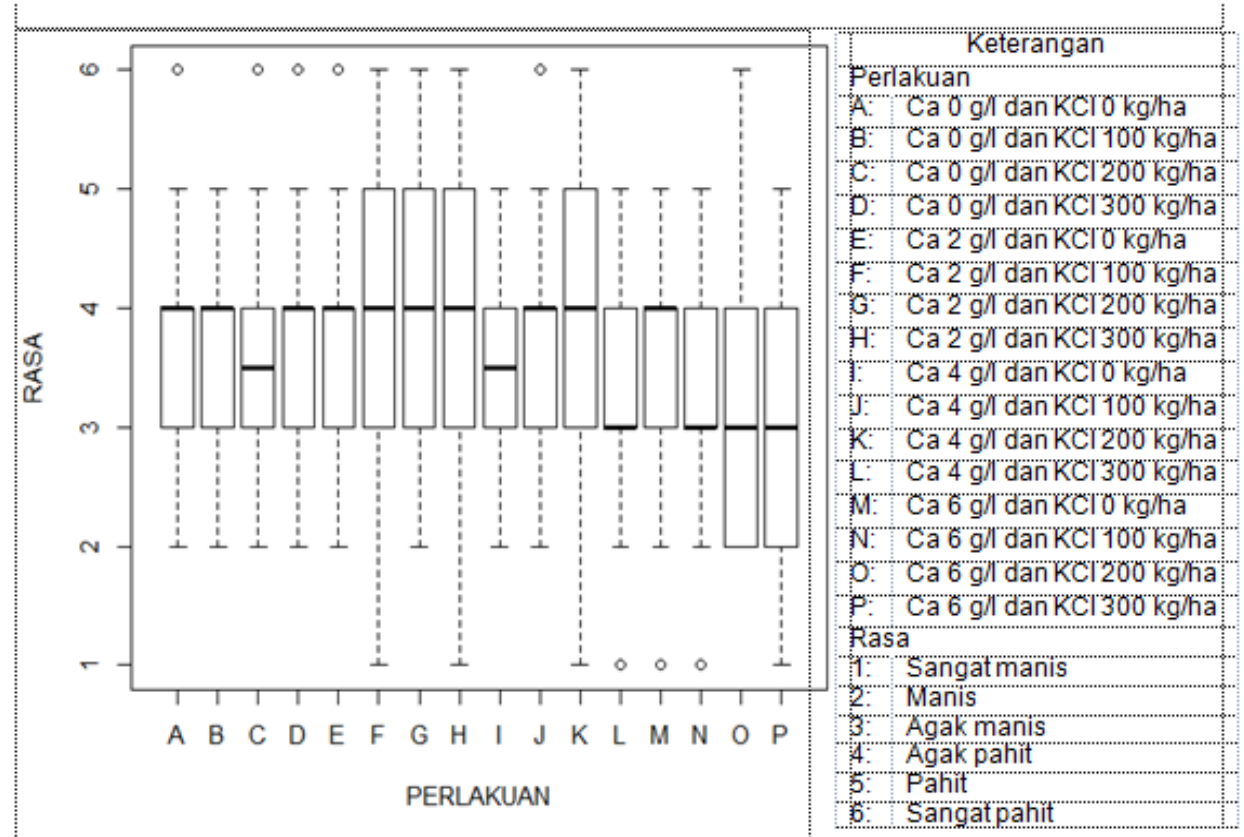

Gambar 2. Boxplot uji organoleptik rasa hasil sawi hijau

Dari pengujian yang dilakukan, varietas Tosakan. Hal ini dapat disebabkan didapatkan bahwa rata-rata nilai tengah rasa karena pada konsentrasi tersebut, laju sawi hijau berada pada angka 4 yang berarti fotosintesis tanaman meningkat sehingga sawi hijau agak pahit, sedangkan rasa yang fotosintat yang dihasilkan dan tersimpan dalam berada pada angka 3 (agak manis) dihasilkan tanaman semakin banyak di dalam daun. oleh oleh daun tanaman sawi hijau dengan Fotosintat yang tersimpan dalam tanaman perlakuan konsentrasi $\mathrm{Ca} 4 \mathrm{~g} / \mathrm{l}$ dan dosis $\mathrm{KCl}$ berupa karbohidrat atau glukosa sehingga $300 \mathrm{~kg} / \mathrm{ha}$, konsentrasi $\mathrm{Ca} 6 \mathrm{~g} / \mathrm{l}$ dan dosis $\mathrm{KCl}$ semakin banyak kandungannya di dalam daun $100 \mathrm{~kg} / \mathrm{ha}$, konsentrasi $\mathrm{Ca} 6 \mathrm{~g} / \mathrm{l}$ dan dosis $\mathrm{KCl}$ $200 \mathrm{~kg} / \mathrm{ha}$, serta konsentrasi Ca $6 \mathrm{~g} / \mathrm{l}$ dan dosis $\mathrm{KCl} 300 \mathrm{~kg} / \mathrm{ha}$. Melalui hasil ini dapat disimpulkan bahwa perlakuan konsentrasi pupuk $\mathrm{Ca} \quad 4 \mathrm{~g} / \mathrm{l}$ dan $\mathrm{Ca} \quad 6$ g/l mampu dapat meningkatkan rasa manis pada daun tanaman sawi hijau. Menurut Rosmarkam dan Yuwono (2002), kekurangan $\mathrm{K}$ yang dapat disebabkan oleh tingginya kandungan $\mathrm{Ca}$ menyebabkan terjadinya kumulatif karbohidrat mempertahankan rasa agak manis dari sawi dalam tanaman. 


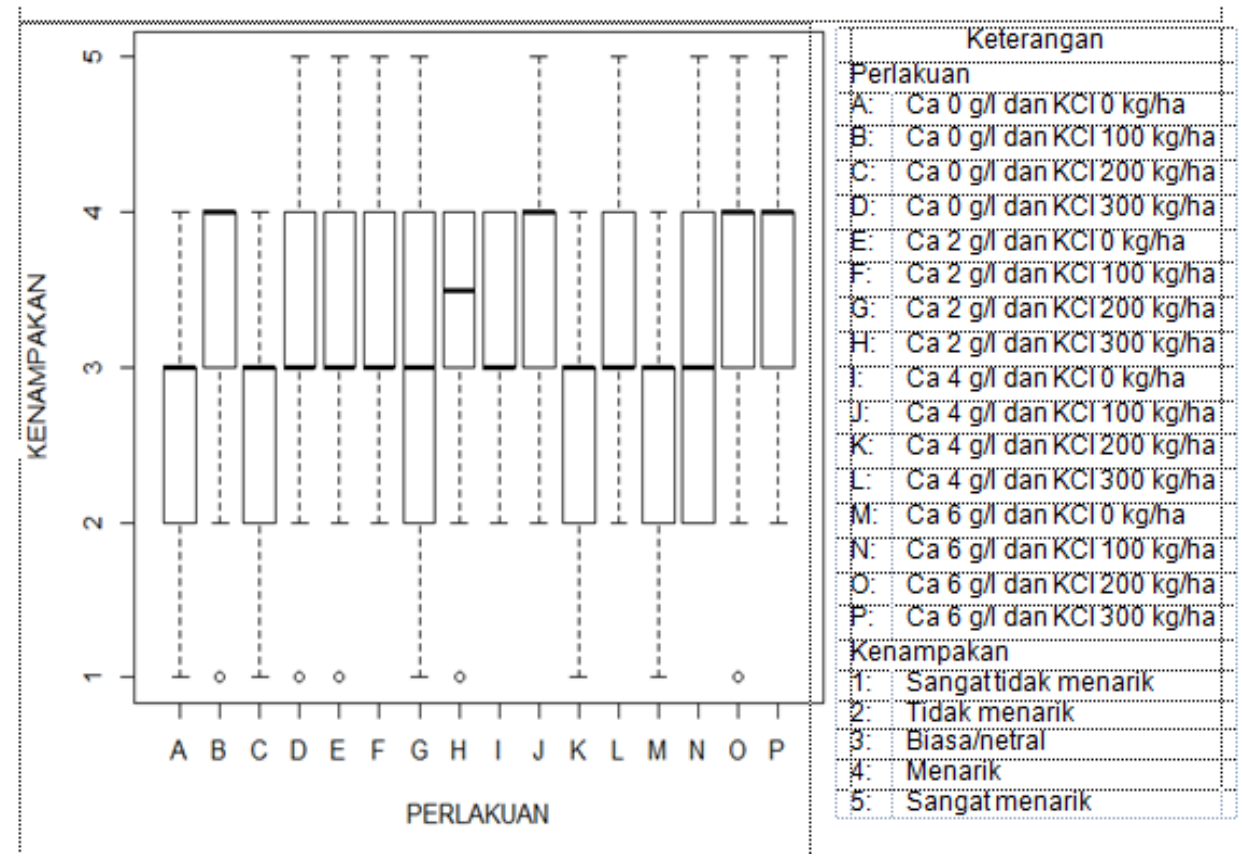

Gambar 3. Boxplot uji organoleptik kenampakan hasil sawi hijau

Dari pengujian yang dilakukan, didapatkan bahwa rata-rata nilai tengah kenampakan sawi hijau berada pada angka 3 yang berarti sawi hijau memiliki penampakan yang biasa, penampakan yang berada pada angka 4 (menarik) dihasilkan oleh daun tanaman sawi dengan perlakuan konsentrasi $\mathrm{Ca} 0 \mathrm{~g} / \mathrm{l}$ dan dosis $\mathrm{KCl} 100 \mathrm{~kg} / \mathrm{ha}$, konsentrasi $\mathrm{Ca} 4 \mathrm{~g} / \mathrm{l}$ dan dosis
$\mathrm{KCl} 100 \mathrm{~kg} / \mathrm{ha}$, konsentrasi Ca $6 \mathrm{~g} / \mathrm{l}$ dan dosis $\mathrm{KCl} 200 \mathrm{~kg} / \mathrm{ha}$, serta konsentrasi Ca $6 \mathrm{~g} / \mathrm{l}$ dan dosis $\mathrm{KCl} 300 \mathrm{~kg} / \mathrm{ha}$. Hal ini menunjukkan bahwa perlakuan konsentrasi $\mathrm{Ca} 6 \mathrm{~g} / \mathrm{l}$ menghasilkan hasil sawi hijau yang menarik karena memiliki warna hijau yang cerah (tidak terlihat layu) dan segar sehingga terlihat menarik untuk dikonsumsi oleh konsumen.

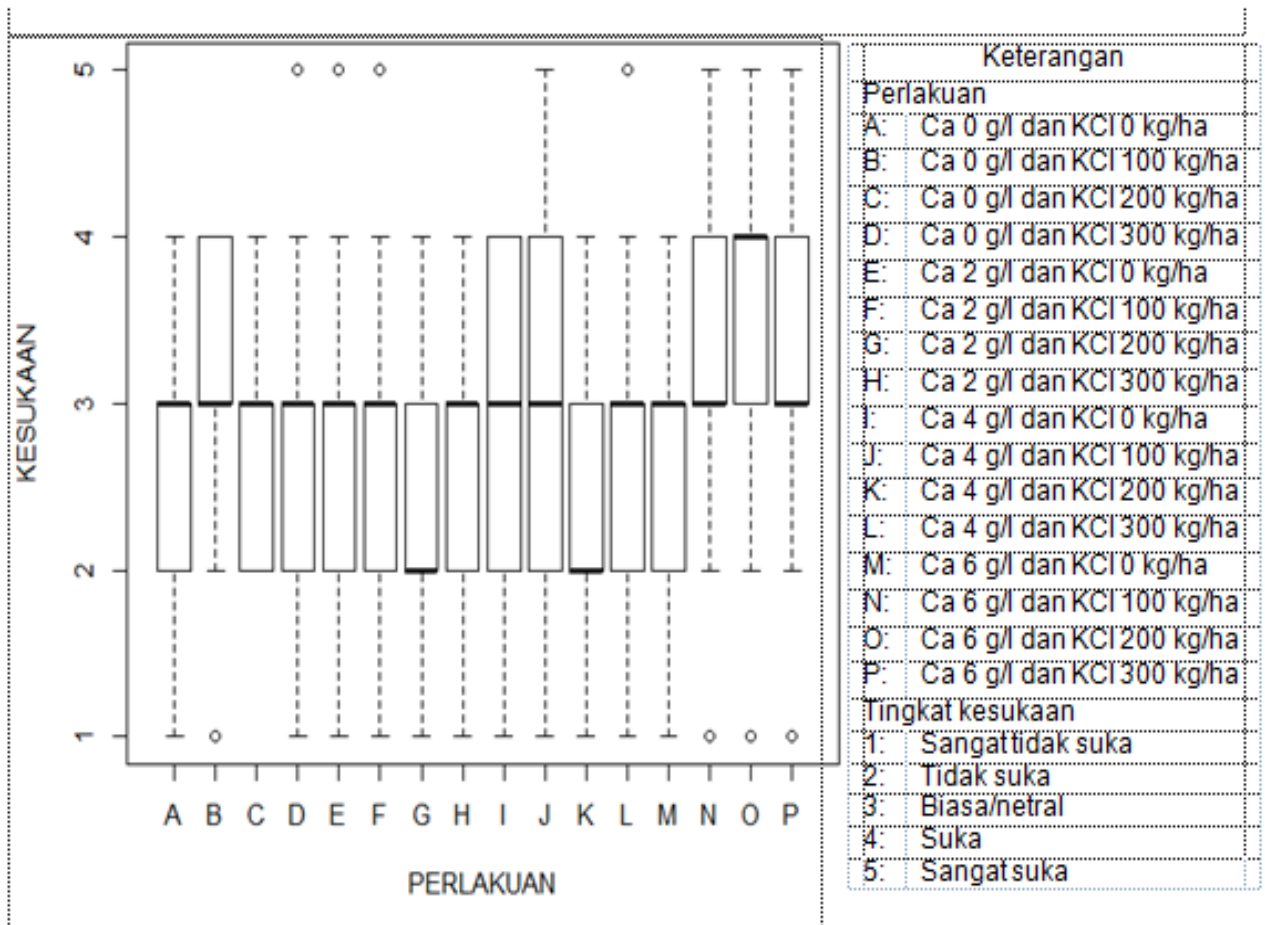

Gambar 4. Boxplot uji organoleptik tingkat kesukaan sawi hijau 
Dari pengujian yang dilakukan, didapatkan bahwa rata-rata nilai tengah tingkat kesukaan sawi hijau berada pada angka 3 yang berarti tingkat kesukaan panelis terhadap sawi hijau netral, sedangkan tingkat kesukaan panelis terhadap sawi hijau tertinggi yaitu berada pada angka 4 (suka) dihasilkan oleh $\mathrm{Ca} 6 \mathrm{~g} / \mathrm{l}$ dan dosis KCl 200 kg/ha. Dari seluruh parameter uji organoleptik yang dilakukan dapat disimpulkan bahwa tanaman sawi dengan perlakuan $\mathrm{Ca} 6 \mathrm{~g} / \mathrm{l}$ mampu meningkatkan kualitas sawi hijau dari segi tekstur, rasa, dan kenampakan yang mempengaruhi tingginya tingkat kesukaan konsumen terhadap sawi yang dihasilkan dengan pengaruh konsentrasi pupuk $\mathrm{Ca}$ tersebut.

\section{KESIMPULAN}

1. Konsentrasi pupuk Ca yang diaplikasikan secara foliar tidak mempengaruhi pertumbuhan dan hasil sawi hijau, namun konsentrasi kalsium $2 \mathrm{~g} / \mathrm{l}$ secara nyata meningkatkan indeks konsumsi sawi hijau.

2. Interaksi antara konsentrasi kalsium dan dosis kalium tidak memperbaiki pertumbuhan dan hasil sawi hijau. Meskipun demikian, ada potensi perbaikan kualitas, terutama tekstur dan rasa dari aplikasi konsentrasi kalsium $4 \mathrm{~g} / \mathrm{l}$ dan $6 \mathrm{~g} / \mathrm{l}$ dengan dosis kalium mulai $100 \mathrm{~kg} / \mathrm{ha}$, sedangkan konsentrasi kalsium $2 \mathrm{~g} / \mathrm{l}$ dan $4 \mathrm{~g} / \mathrm{l}$ dengan dosis kalium $200 \mathrm{~kg} / \mathrm{ha}$ menghasilkan sawi hijau yang paling disukai oleh koresponden.

3. Dosis pupuk $\mathrm{KCl}$ tidak mempengaruhi pertumbuhan dan hasil sawi hijau, dan semakin tinggi dosis mulai $300 \mathrm{~kg} / \mathrm{ha}$ justru menurunkan berat segar tajuk sawi hijau.

\section{DAFTAR PUSTAKA}

Blakemore, L. C., P.L. Searle, and B.K. Daly. 1987. Methods for Chemical Analysis of Soils. Department of Scientific and Industrial Research. Lower Hutt.

DGDK (Direktorat Gizi Departemen Kesehatan Republik Indonesia). 2012. Komposisi Kimia Sawi Hijau. Depkes RI. Jakarta.

Easterwood, G.W. 2016. Calcium's Role in Plant Nutrition. <https://fluidfertilizer.org/wpcontent/uploads/2016/05/36P1619.pdf>. Diakses 12 Juli 2019.

Faranso, D. dan A.D. Susila. 2015. Rekomendasi pemupukan fosfor pada budidaya caisin (Brassica rapa L. cv. caisin) di tanah andosol. Jurnal Hortikultura Indonesia. 6(3):135-143.

Kementerian Kelautan dan Perikanan. 2006. Metode Uji Organoleptik dan Fisika. <https://kkp.go.id/bkipm/page/115-snikarantina-ikan-dan-mutu>. Diakses 1 Oktober 2019.

Khan, F.A., S. Narayan, M.K. Prajapati, and R. Narayan. 2017. Calscium deficiency disorders and their management in vegetable. Journal of Horticultural Science and Biotechnology, 84(6):577584.

Ochmian, I.D. 2012. The impact of foliar application of calcium fertilizers on the quality of highbush blueberry fruits belonging to the 'Duke' cultivar. Notulae Botanicae Horti Agrobotanici Clujna poca, 40(2). 
Opena, R.T. and D.C.S. Tay. 1994. Plant Resource of South-East Asia Volume 2: Vegetable. Backhuy. Kerkwerve.

Rosmarkam, A. dan N.W. Yuwono. 2002. IImu Kesuburan Tanah. Penerbit Kanisius. Yogyakarta.

Sitompul, S.M. dan B. Guritno.1995. Analisis Pertumbuhan Tanaman. Gadjah Mada University Press. Yogyakarta.

Yucel, H., S. Sahin, N. Saglam, M. Aydin, P. Cakmak, and N. Gebologlu. 2013. Foliar applications of $\mathrm{Ca}, \mathrm{Zn}$, and urea on crispy lettuce in soilless culture. Soil-Water Journal. 2(2):24-30. 